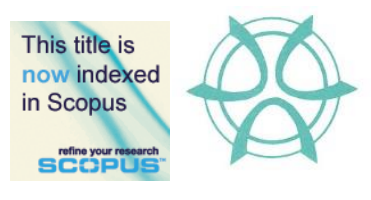

PLANNING MALAYSIA:

Journal of the Malaysian Institute of Planners

VOLUME 16 ISSUE 2 (2018), Page 39 - 49

\title{
DESIGN ANALYSIS TO ACHIEVE GREEN/ECO SCHOOL BUILDING DESIGN TYPOLOGY FOR MALAYSIA
}

\author{
Zuraini Denan', Muhammad Afiq Helmi Mazlan², Noor Hanita Abdul \\ Majid $^{3}, \&$ Nur Aliyah Zafirah Sanusi ${ }^{4}$ \\ ${ }^{1,2,3,4}$ Kulliyyah of Architecture and Environmental Design \\ INTERNATIONAL ISLAMIC UNIVERSITY MALAYSIA
}

\begin{abstract}
Ever since the first establishment of the public school (primary and secondary school) in Malaysia, the building design for most of the schools is almost the same until now. Public school for primary and secondary education is based on a standard layout designed by the Malaysian Public Works Department. Evolution of varieties education system employed by the schools does not affect the physical design of school. The emergence of awareness on sustainability and promotion towards green way of life has made it crucial for designer to rethink the best design for school in enhancing its environment that could be the "third teacher" to the pupils. The research attempt to explore design criteria of green school in Malaysia based on the critical elements of green initiatives. Recommendation of green/eco school design will be presented based on site and building planning, climate and green technology application
\end{abstract}

Keywords: school, green, design, environment, education 
Zuraini Denan, Muhammad Afiq Helmi Mazlan, Noor Hanita Abdul Majid, \& Nur Aliyah Zafirah Sanusi Design Analysis to Achieve Green/Eco School Building Design Typology for Malaysia.

\section{INTRODUCTION}

The education system in Malaysia has changed occasionally, yet the physical form of the school remains almost the same. More schools (primary and secondary) were built to fulfill the needs of the children education in Malaysia. A total of 10,117 number of school buildings; excluding the number of preschool, was recorded in Malaysia (Roslizar, Alghoul, Bakhtyar, Asim, \& Sopian, 2014). The same prototype school building design was repeated all over Malaysia.

The space planning of standard school building design are based on the syllabus of the latest curriculum for primary and secondary schools (Kurikulum Baru Sekolah Rendah and Kurikulum Baru Sekolah Menengah) governed by the Ministry of Education. Number of courses or subjects required determine the number of classes and type of classroom (i.e: music room, laboratories, halls or outdoor space/areas, etc).

Commonly, layout of standard schools is arranged in linear spatial organization with one sided corridor. Two blocks of three or up to five stories block are facing each other with a courts in a middle. Two blocks that faced each other are connected with a bridge where shared staircases are designed in the middle or merely just a bridge for connectivity. Fire staircases are located either in the middle or at the end of the block, while toilets are always located at the end of the block. Other blocks for halls, laboratories, workshop, canteen, musholla are another separated physical building form. These are basic architectural form and spaces which are required by a school to accommodate subjects such as science, mathematics, geography, history and religion. Gardens are used more like yards or working compound for specific subjects such as science or vocational landscape or co-curriculum activities. The existence of green surrounding is not emphasizing as maintenance to keep it clean, manageable and safe for the children can increase maintenance budget for the school.

The environment and the physical surrounding of public schools do not really encourage the learning through nature or school as 'third teacher' or a laboratory for the green and sustainable living experience.

\section{ISSUES AND PROBLEM}

To develop physical form and space of an existing school to accommodate green design strategies is a challenge. In green school program students are required to connect with nature, however the layout and space planning of school design not allowed much freedom to allocate space for such activities; to grow plants, to keep and manage recycle materials and to process composite. The landscape of school complex is commonly laid with concrete or tarmac for easy maintenance. In a hot humid country such as Malaysia to have a well maintained green landscape is not an easy task. The hardscape surrounding has increased the temperature and bring glare and heat which make it uncomfortable for students 
PLANNING MALAYSIA

Journal of the Malaysia Institute of Planners (2018)

and staff. Study have shown that the environment of teaching and learning has tremendous effect on academic performances. Environmental factors has affected $73 \%$ of the score in student scores ("School Design, Classroom Layout", 2013).

\begin{abstract}
AIM AND OBJECTIVES
The study attempts to propose a suitable design of school physical form and space in order to use school as the living laboratory in motivating green initiatives in school. The proposed design evaluated based on the optimum recommendation of of the school will be based on the site and building planning, climate, and green technology application.
\end{abstract}

\title{
METHODOLOGY
}

A design thesis proposal (Mazlan, 2016) is presented as an experimental process in searching for the suitable green school form and space layout. The analysis is focussed on creating a comfortable environment due to climate and placing green technology application.

\section{GREEN SCHOOL CRITERIA}

Teaching and learning environment has tremendous effects on students' performance (Higgins, Hall, Wall, Woolner, \& McCaughey, 2016; Schneider, 2002). The world has realized that by establishing a green school or eco school program, the teaching and learning environment which are based on nature will change the future education paradigm. Eco or green school is an international programme that lead to sustainable development. Study shows that green school program can reduce absenteeism and increase test score (US EPA), 2017).

In the eco or green school program, each school is recommended to apply six themes: 1. Waste and litter, 2. Water, 3. Energy, 4. School Grounds, 5. Nature and Biodiversity and 6. Climate and Change. It is not easy to apply all, most green school interpret the six themes into application of green technology such as install photovoltaic solar panel, harvest rainwater, recycle waste and reuse material, plant trees and grow edible plants for usage. Case studies done in this region shows that Green school in Bali, Indonesia is the best green school example (Denan et al., 2017). 
Zuraini Denan, Muhammad Afiq Helmi Mazlan, Noor Hanita Abdul Majid, \& Nur Aliyah Zafirah Sanusi Design Analysis to Achieve Green/Eco School Building Design Typology for Malaysia.

\section{GREEN SCHOOL DESIGN CONSIDERATION}

\section{Site Planning}

In searching for a conducive and comfortable learning and teaching environment, passive design concept is emphasized. Not only site planning focus on accessibility, security and maximization of space on site, but building orientation is also considered due to avoid over exposure to heat and sun. Figure 1 shows the site planning process in searching the best orientation based on program distribution (academic, administration and services), exterior frontage, green pocket areas, assembly area and vehicular and pedestrian access.

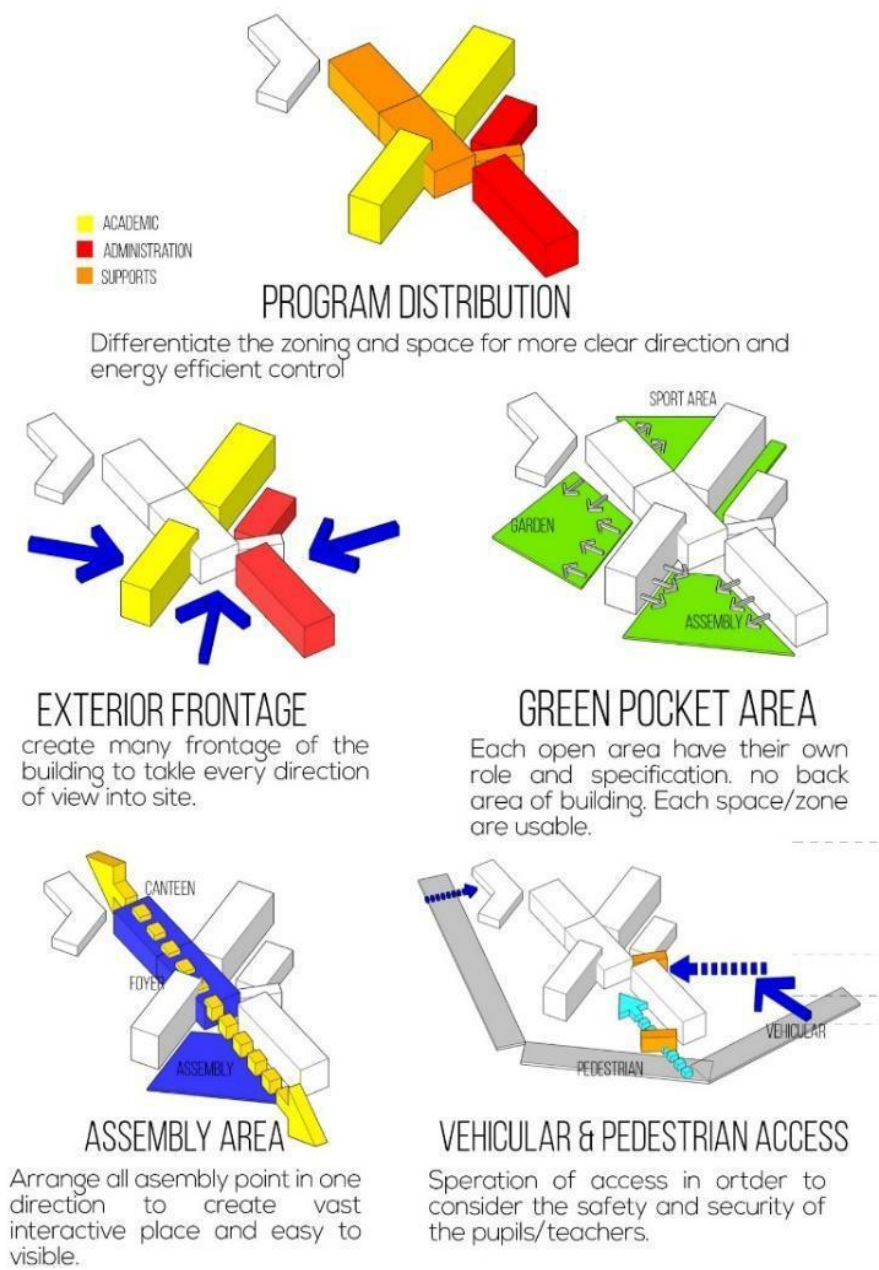

Figure 1(a): Site Planning and Design process Source: Mazlan (2016) 

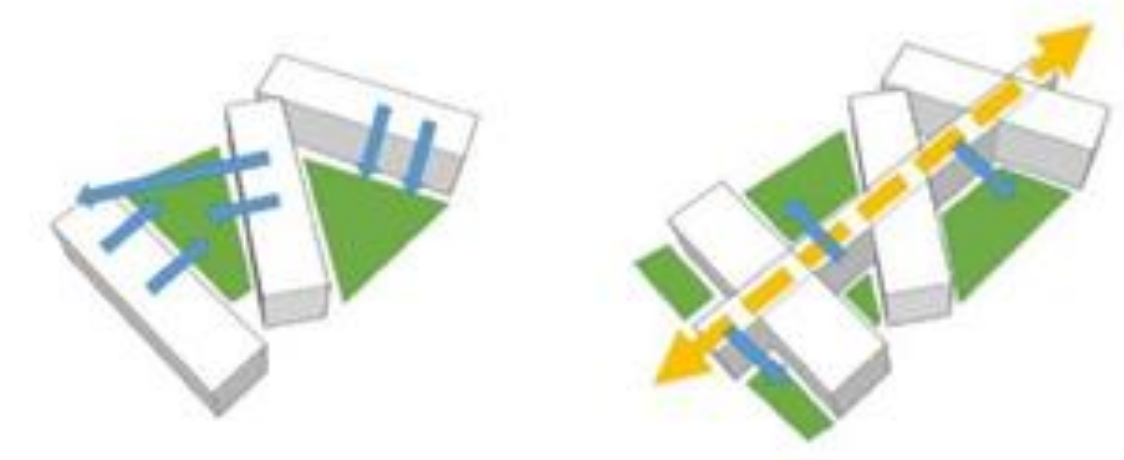

Figure 1(b): Site planning with green pocket and middle spine for connectivity in between blocks.

\section{Passive Design}

Passive design feature is one of the strategy to achieve green and sustainable design. Orientated the longest façade building facing the south and north, the building has less exposure area toward direct sunlight. It will reduce the heat absorb to the building. Besides that, creating a proper positioning of the building based on the sun orientation will create a shadow in the area where pupils mostly have their assembly. Shadow, solar radiation and day lighting analysis are among suitable evaluation to determine design components that response to the climate, in this case the humidity of Malaysia. The evaluation will also influence the installation of green technology such as solar photovoltaic panel and rain water harvesting.

\section{Shadow Casting Analysis}

The intention of the designer is to design based on the student movement which the shaded area occur based on the student activities. For example, assembly area in the morning area shaded for the student during daily morning assembly while during evening, shaded area have moved to the sport zone where the student did not expose too much to sun radiation during co-curriculum activities. The shadow casting (Figure 2) shows the spine of the building is shaded all the time. It was a good place for the people to conduct an event or activities all day during school time. The shaded spine allowed the student to play and learn at the outdoor area. 


\section{SHADOW CASTING}

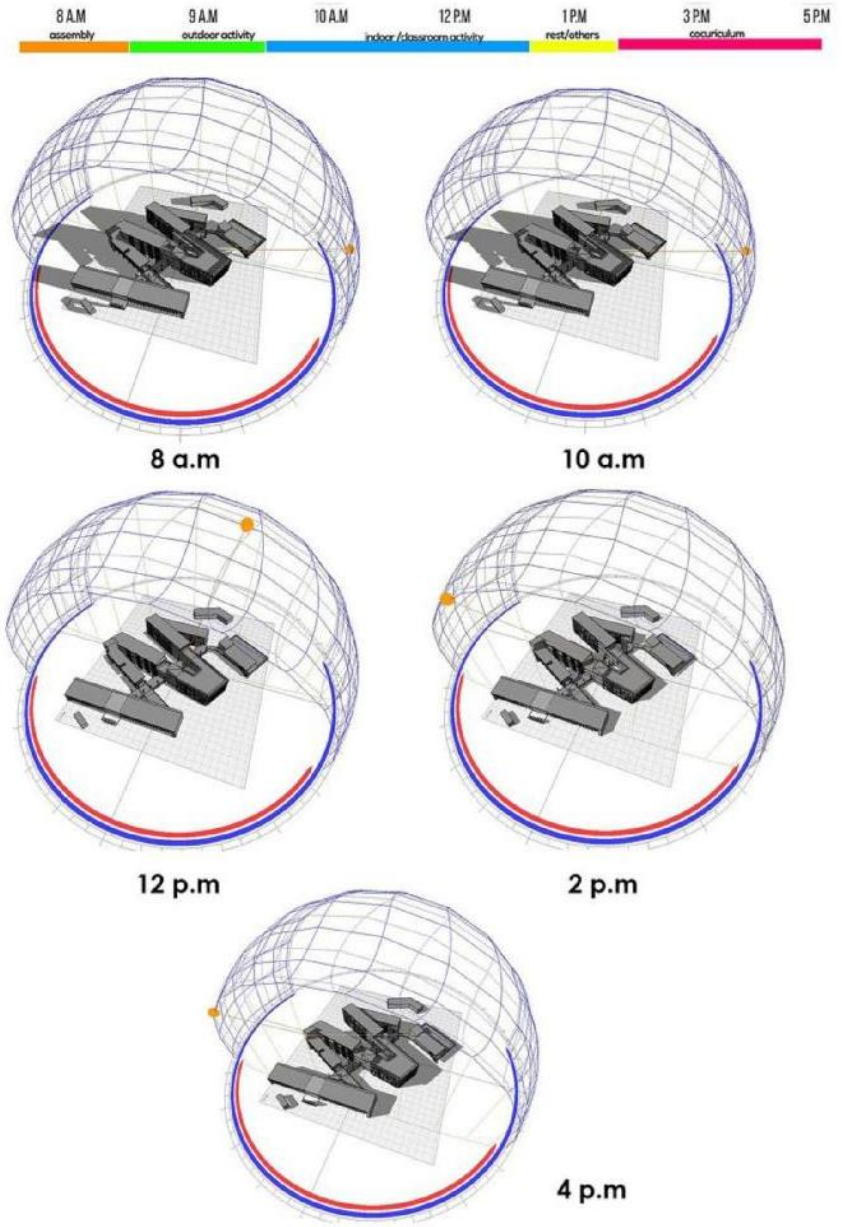

Figure 2: Shadow casting Analysis Source: Mazlan (2016)

\section{Solar Radiation Analysis}

Thus, all of these strategies not only apply in the design theoretically but it has been proved by the simulation using the ecological software itself. Herewith the analysis done to the proposed eco-school building; the solar radiation analysis showed that most of the roof were the most exposed area to the direct sunlight with average daily radiation is more than $6 \mathrm{kwh} / \mathrm{m} 2$ (Figure 3). It is the amount they received every day. On the other hand, all the school block showed they only received $0.6 \mathrm{kwh} / \mathrm{m} 2$ to the surface of the building. Its showed that that building 
PLANNING MALAYSIA

Journal of the Malaysia Institute of Planners (2018)

was getting less heat from direct sunlight. The result also showed the suitable spot to place photovoltaic solar is on the roof.

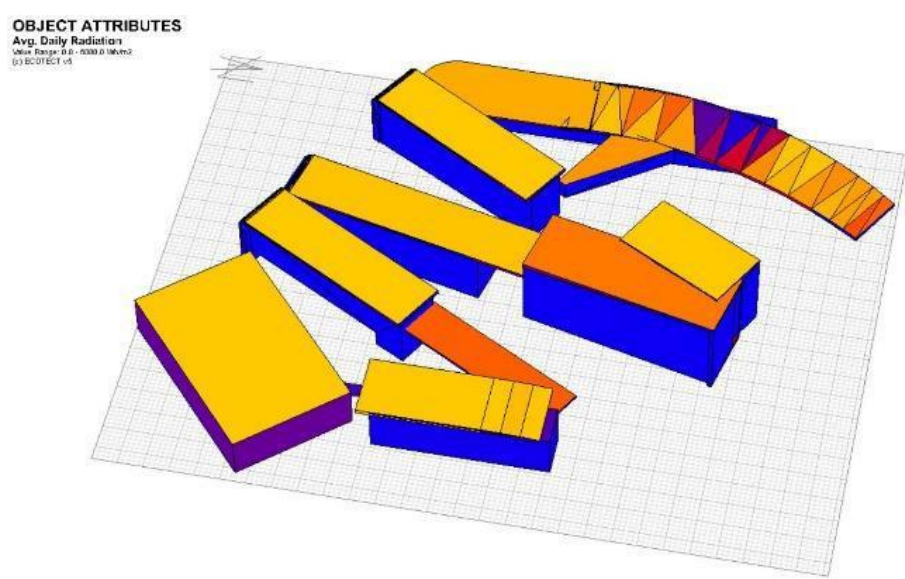

Figure 3: Solar radiation analysis of the building

\section{Daylighting Analysis}

The result showed that the area between the block receiving almost $70 \%$ of natural lighting in the area. It was proved that the area had ample natural lighting for reading and not required artificial lighting in the area. The garden between the block would received enough natural daylight for the plants and trees. However, spine of the building only received $60 \%$ of daylighting. It was still good enough to have an activity in the area because they were more shaded than the landscape or the garden area. Therefore, the area surrounding the building had ample daylighting to hold activities outside the classroom.

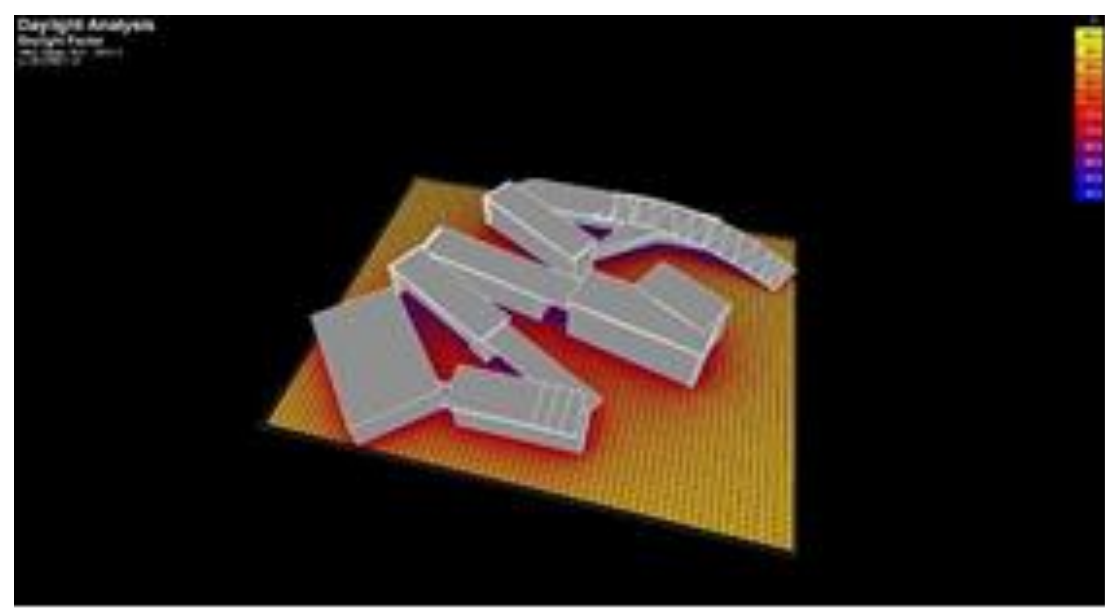

Figure 4: Daylighting analysis result of the building 
Zuraini Denan, Muhammad Afiq Helmi Mazlan, Noor Hanita Abdul Majid, \& Nur Aliyah Zafirah Sanusi Design Analysis to Achieve Green/Eco School Building Design Typology for Malaysia.

\section{Green Technology}

Photovoltaic (PV) Solar Panel

The proposed design responded to the sun orientation. The roof of each block is facing more toward south to gain more exposure hours of the sun. There are no obstacle that prevent direct sunlight to the PV panel. Figure 5 shows the most suitable roof location after taking into consideration of the angle and azimuth in order to gain more exposure hours of direct sunlight to generate more electricity energy. The area only at Academic 1 block, administration block, hall, and the spin roof.

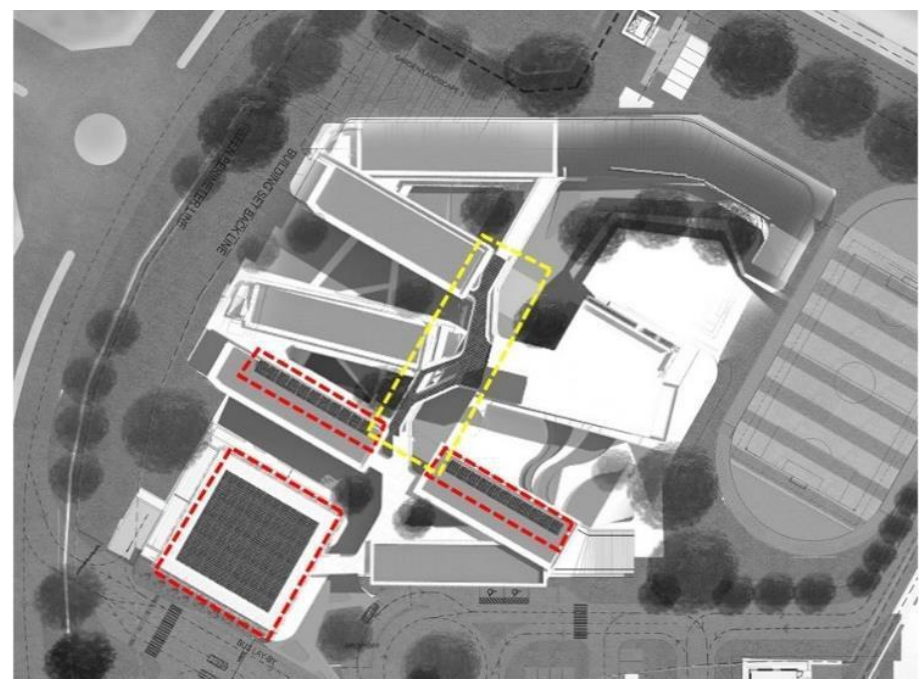

Figure 5: The area of PV panel location. The red one is for the commercial use while the yellow one is for the educational purposes. Source: Mazlan (2016)

\section{Rainwater Harvesting}

The usage of rainwater harvesting in green/eco-school is to collect all the rainwater into the one area before use it to water the garden and edible yards. This will reduce cost of water expenses and enhance the green surrounding and beautiful landscape. The rain water collecting system will be placed in each green roof intensive or extensive and at the garden roof in the canteen. The diagram below shows how the rainwater system operates and locate in the garden roof and green roof in green school (Figure 6). 


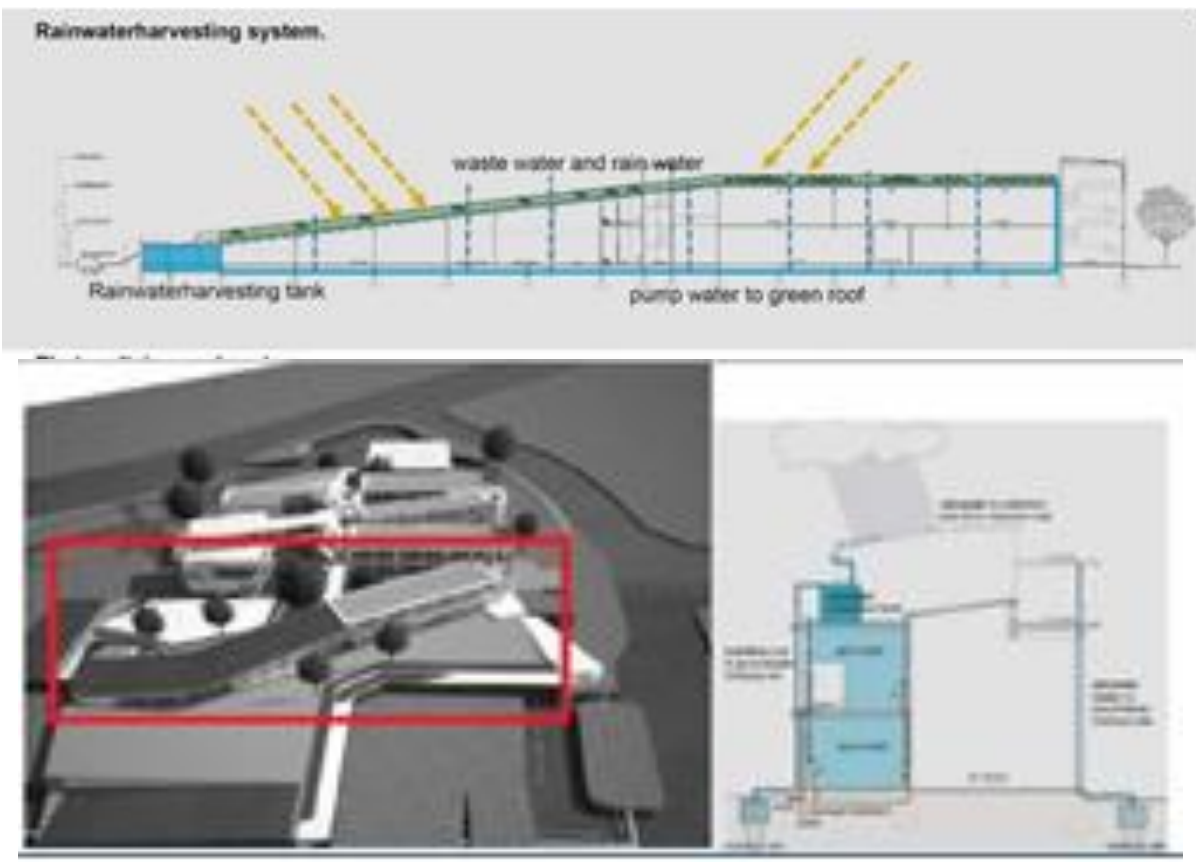

Figure 6: The diagram of rainwater harvesting system for the garden roof and its location in the school building.

$$
\text { Source: Mazlan (2016) }
$$

\section{Details on Classroom Design}

The dimension of typical classroom was adjusted. The typical classroom dimension is $7500 \mathrm{~mm} \times 9000 \mathrm{~mm}$ which is equivalent to $68 \mathrm{sqm}$. A dimension of green classroom is $8000 \mathrm{~mm} \times 12000 \mathrm{~mm}$ equivalent to $90 \mathrm{sqm}$. The classroom floor plate was designed bigger but thinner in order to allow more air flow ventilated through the classroom. Besides that, the green classroom was to create more room for the student in order to make the classroom 1:35 or 1:40 ratio rather than 1:30. However the size of the classroom could be adjusted depends on the size and no of occupant of the school but maintaining the ratio of classroom dimension. Figure 7 below show the eco classroom concept and its simulation.

The garden corridor was one of the area/space for children of student to take a rest between 2 period subjects. The corridor was provided with planter box for children to plant their own plant. It was one of the environmental education program (EE) which was one pot one children program. 
Zuraini Denan, Muhammad Afiq Helmi Mazlan, Noor Hanita Abdul Majid, \& Nur Aliyah Zafirah Sanusi Design Analysis to Achieve Green/Eco School Building Design Typology for Malaysia.
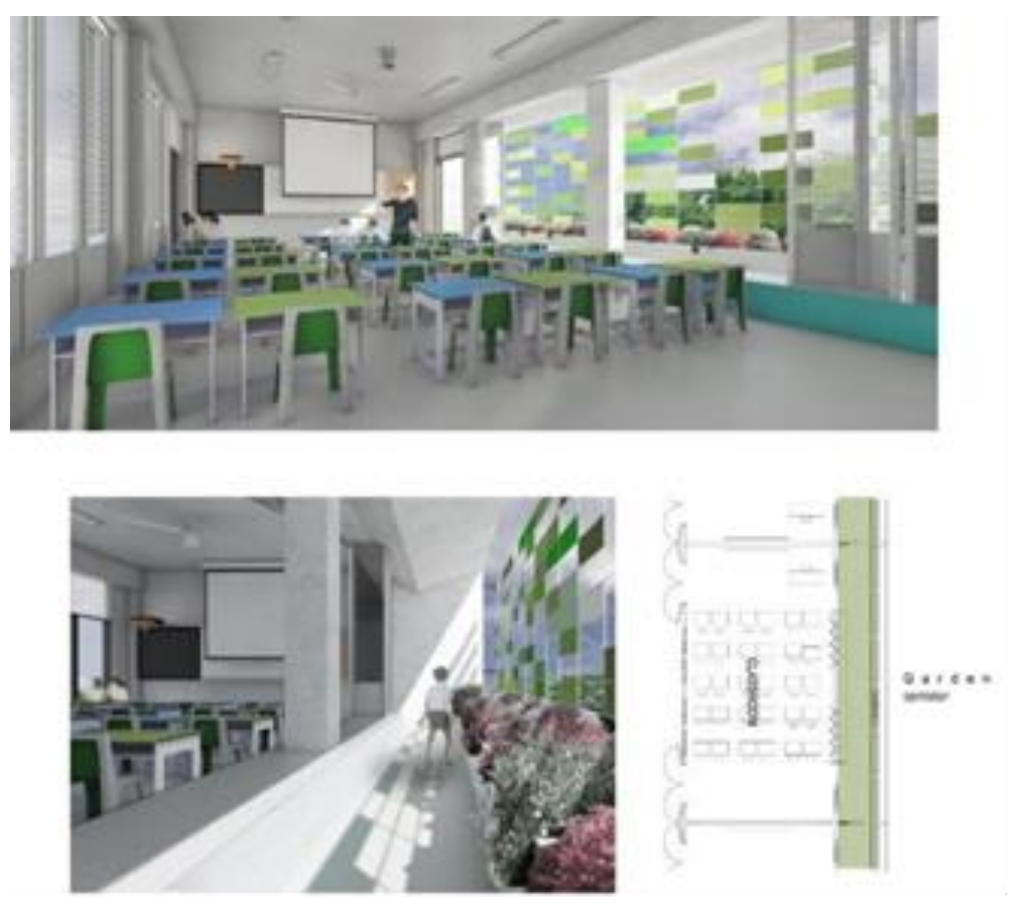

Figure 7: Classroom design with green corridor.

\section{RESULTS AND FINDINGS}

The proposed design has taken into consideration the most crucial factors such as site planning, climatic consideration, and green technology application. These has form a unique design with blocks orientated in a zigzag layout to avoid over exposure to the sun and its heat and at the same time creating green pockets for outdoor activities which are shaded. The blocks orientation also offers good location for the PV solar panel to be laid on the roofs. Having a spine connected to the end block are conducive space for student's assembly and as part of roof top platform for rain water harvesting system. Other detail features such as green balcony and wall and garden plots at the back of the blocks are supporting strategies which will enhance the green school activities and image (Figure 8).

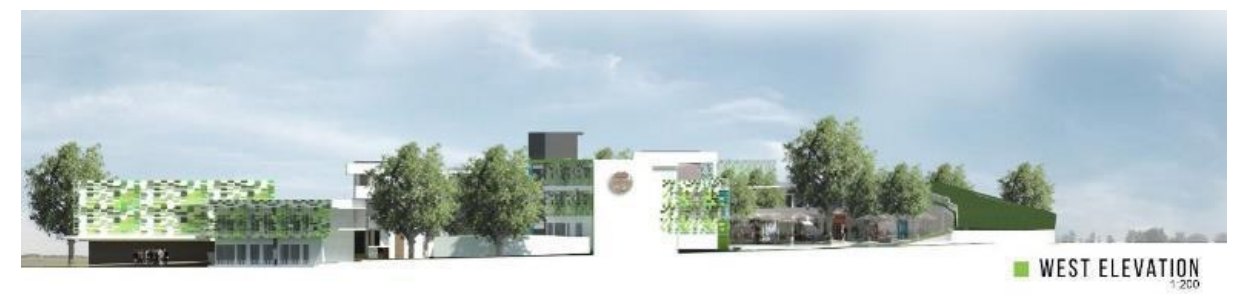




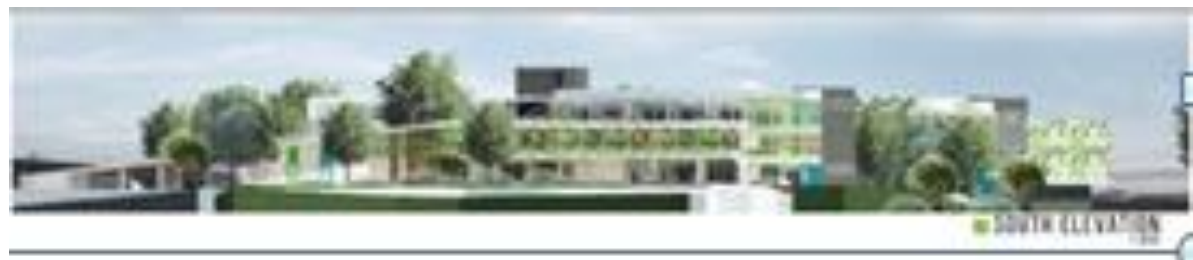

Figure 8: Elevation of the whole school block showing the image of green school

\section{CONCLUSION}

The design shows that a comfortable teaching and learning environment that is based on climatic analysis and recommended green strategies proposal have high potential to be adopted as an option to a refreshing and stimulating teaching and learning environment for public school in Malaysia. No extreme design is proposed as to keep the maintenance low and safety of the children are under control.

\section{REFERENCES}

Denan, Z., Awang, A. H., Mazlan, M. A. H., Majid, N. H. A., Rahim, Z. A., \& Sanusi, N. A. Z. (2017). The implementation of environmental education and green programs in schools to achieve sustainability. Advance Science Letter, 23(7), 6261-6265.

Higgins, S., Hall, E., Wall, K., Woolner, P., \& McCaughey, C. (2005). The impact of school environments: A literature review. University of Newcastle.

Mazlan, M. A. H. (2016). Proposed eco school, Desa Park City (Unpublished Thesis). IIUM, Malaysia.

Roslizar, A., Alghoul, M. A., Bakhtyar, B., Asim, N., \& Sopian, K. (2014). Annual energy usage reduction and cost savings of a school: End-use energy analysis. The Scientific World Journal, 1-8. http://doi.org/10.1155/2014/310539

Schneider, M. (2002). Do school facilities affect academic outcomes. Washington USA: National Clearinghouse for Educational Facilities.

School Design, Classroom Layout Can Heavily Affect Student Grades, Learning: Study
(2013,
March
$1)$.
Retrieved
from

https://www.huffingtonpost.com/2013/01/03/school-design-studentgrades_n_2404289.html

United States Environmental Protection Agency [US EPA] (n.d.). Overview of design and construction for a healthy school environment. Retrieved October 10, 2017, from http://www.epa.gov/schools-healthy-buildings/overview-design-andconstruction-healthy-school-environment. 